\title{
ПРЕВЕНЦІЯ БУЛІНГУ В УМОВАХ СТВОРЕННЯ БЕЗПЕЧНОГО ОСВІТНЬОГО СЕРЕДОВИЩА
}

\begin{abstract}
Кваша А. С.
здобувач третього (освітньо-наукового) рівня вищої освіти кафедри початкової і професійної освіти, Харківський національний педагогічний університет імені Г. С. Сковороди, м. Харків, Україна

Актуальність проблеми забезпечення безпечного освітнього середовища зумовлена зростаючою динамікою небезпечних ситуацій, тому безпека є обов'язковою умовою і одним з критеріїв ефективності дiяльності закладу освіти. Булінг (цькування) розглядається як реальна загроза безпеиі сучасного освітнього середовища.
\end{abstract}

Ключові слова: булінг, загроза, безпечне освітнє середовище.

The urgency of the problem of ensuring a safe educational environment is due to the growing dynamics of dangerous situations, so safety is a prerequisite and one of the criteria for the effectiveness of the educational institution. Bullying is seen as a real threat to the security of today's educational environment.

Key words: bullying, threat, safe educational environment.

Незважаючи на численні дослідження присвячені створенню безпечного освітнього середовища, ця проблема вивчена недостатньо. Для створення безпечного освітнього середовища необхідно чітко розуміти, які небезпеки та загрози є в сучасному освітньому середовищі і мати інструментарій їхньої оцінки.

Автори посібника «Кодекс безпечного освітнього середовища» безпечне освітнє середовище тлумачать як «стан освітнього середовища, в якому: наявні безпечні умови навчання та праці, комфортна міжособистісна взаємодія, що сприяє емоційному благополуччю учнів, педагогів і батьків, відсутні будь-які прояви насильства та є достатні ресурси для їх запобігання, а також дотримано прав і норм фізичної, психологічної, інформаційної та соціальної безпеки кожного учасника навчально-виховного процесу», а його складниками $€$ : якість міжособистісних відносин, захищеність в освітньому середовищі, комфортність в освітньому середовищі, задоволеність освітнім середовищем [7, с. 10-11]. 
I. Баєва до основних показників рівня безпеки освітнього середовища відносить: задоволеність основними аспектами взаємодії учасників освітнього процесу, захищеність від насильства і референтність середовища, які за позитивної динаміки можуть бути умовами гармонізації психічного здоров'я суб'єктів освітнього процесу [3].

Проаналізувавши основні підходи до розуміння булінгу зарубіжними авторами, В. Петросянц виокремила загальні характеристиками булінгу в освітньому середовищі:

- булінг — це насильство (фізичне, психологічне, емоційне);

- булінг здійснюється однією особою або групою осіб;

- булінг спрямований проти особи, яка завідомо слабше психологічно або фізично;

- булінг має систематичний та тривалий характер [4, с. 152].

Існує думка про те, що в освітньому середовищі доцільно розглядати як загрозу булінгу, так і мобінгу, а їхні сутнісні відмінності полягають у кількості суб'єктів цькування [2; 8]. Не можемо погодитися з такою думкою, адже поняття мобінгу законодавчо не закріплене, натомість булінг (цькування) як діяння (дії або бездіяльність) учасників освітнього процесу не має диференціації щодо кількості учасників [5].

У додатку до листа МОН України від 14.08.2020 № 1/9-436 зазначено, що ефективним інструментом запобігання проявам булінгу (цькування) у закладі освіти є його профілактика, тому в закладі освіти має панувати атмосфера спільної поваги і відповідального ставлення один до одного [6].

Т. Алєксєєнко вважає, що профілактична робота повинна включати в себе діагностику проявів булінгу у шкільному колективі, цілеспрямовані заходи виховної роботи зі школярами та моніторинг ситуації [1, с. 23].

Світовий досвід наглядно демонструє, що безпека освітнього середовища може бути досягнута шляхом формування позитивного світогляду, цінностей і норм поведінки учасників освітнього процесу, а це можливо завдяки впровадженню програм попередження (превенціi) булінгу. 


\section{Список використаних джерел:}

1. Алєксєєнко Т. Булінг і мобінг: причини розвитку і шляхи профілактики. Науковий вісник міжнародного гуманітарного університету. 2018. № 10. C. $19-25$.

2. Алєксєєнко Т. Явища мобінгу й булінгу у взаєминах особистості та колективу. Управління освітою. 2019. №4. С. 46-53.

3. Баева И. А. Психологическая безопасность образовательной среды: теоретические основы и технологии создания : дис. ... д-ра психол. наук : 19.00.07 Санкт-Петербург. Росс. гос. пед. универ. им. А. И. Герцена. Санкт-Петербург, 2002. 386 с.

4. Петросянц В. Р. Проблема буллинга в современной образовательной среде. Вестник ТГПУ. 2011. Выпуск 6(108). С. 151-154.

5. Про внесення змін до деяких законодавчих актів України щодо протидії булінгу (цькуванню) : Закон України від 18.12.2018 № 2657-VIII. URL: https://zakon.rada.gov.ua/laws/show/2657-19\#Text (дата звернення: 12.10.2021).

6. Про створення безпечного освітнього середовища в закладі освіти та попередження і протидії булінгу (цькуванню) : лист МОН від 14.08.2020 № 1/9-436. URL: https://mon.gov.ua/ua/npa/pro-stvorennya-bezpechnogoosvitnogo-seredovisha-v-zakladi-osviti-ta-poperedzhennya-i-protidiyibulingu-ckuvannyu (дата звернення: 12.10.2021).

7. Цюман Т. П., Бойчук Н. І. Кодекс безпечного освітнього середовища: метод. посіб. / за заг. ред. Цюман Т. П. Київ, 2018. 56 c. URL: https://mon. gov.ua/storage/app/media/zagalna\%20serednya/protidia-bulingu/21kbos.pdf (дата звернення: 12.10.2021).

8. Юрко Н. А., Стифанишин І. М., Проценко У. М., Тиндик Н. А. Безпечне освітнє середовище: основні характеристики мобінгу та булінгу. $\Lambda$ 'ОГО $\Sigma$. ОНЛАЙН. URL: https://www.ukrlogos.in.ua/10.11232-2663-4139.11.02.html (дата звернення: 12.10.2021). https://doi.org/10.36074/2663-4139.11.02. 